Aleksander Swieżaw ski

\title{
Plany koronacyjne Henryka Probusa Królestwo polskie czy królestwo krakowskie?
}

\section{Krönungspläne von Heinrich dem Probus. Polnisches oder krakauer Königsreich?}

1. Przekazanie Przemysłowi idei odrodzenia Królestwa Polskiego. 2. Koronacyjna obietnica Henryka. 3. Okoliczności związane z planami koronacyjnymi. 4. O jakim królestwie myślał Henryk Probus? 5. Zamiar utworzenia królestwa krakowskiego.

1. Übergabe an Przemysł der Idee der Wiederbelebung des Polnischen Königsreiches. 2. Das Krönungsversprechen von Heinrich. 3. Mit Krönungsplänen verbundene Umstände. 4. An welches Königsreich hat Heinrich der Probus gedacht. 5. Die Absicht der Gründung des krakauer Königsreiches.

1. Testament, w którym Henryk Probus zapisuje Przemysłowi II ziemie krakowską i sandomierską ${ }^{1}$ lączy się $\mathrm{w}$ opinii historyków $\mathrm{z}$ dążeniami tego księcia do pozyskania korony polskiej. Ponieważ Henryk w obliczu niespodziewanej śmierci zrozumial, że swych planów koronacyjnych nie będzie mógł zrealizować, przekazał Przemysłowi Małopolskę niejako wraz z ideą odnowienia królestwa polskiego. Dla dziejopisarzy bowiem nie ulega wątpliwości, że Henryk w swych projektach mógl brać pod uwage tylko koronę polską. Spróbujmy zatem prześledzić kroki Henryka w kierunku pozyskania korony i ocenić realne możliwości zdobycia przez niego polskiego tronu królewskiego.

2. Około $1280 \mathrm{r}$. Henryk zawarł związek małżeński z nieznaną z imienia córką księcia opolskiego Władysława ${ }^{2}$. Przy tej okazji obiecał swemu

\footnotetext{
KDWp, t. II, wyd. I. Zakrzewski, Poznań 1878, nr 645.

${ }^{2}$ W. Dworzaczek, Genealogia. Tablice, Warszawa 1959, tabl. 5, 9; K. J a siński, Rodowód Piastów ślquskich, t. I, Wrocław 1973, s. 161.
} 
teściowi, że gdy uzyska królestwo i koronę w Polsce (regnum et coronam in Polonia), to ukoronuje też jego córkę, a swoją żonę, na królową ${ }^{3}$. Roman Grodecki, chociaż podkreśla, iż Henryk mówil tylko o pozyskaniu regnum in Polonia, a nie regnum Poloniae (co wskazuje, że projektowane królestwo mogloby objąć tylko część Polski), to jednak, opierając się na sojuszu Henryka z Bolkiem opolskim i jego układami z Henrykami, głogowskim i legnickim, z 1281 r., sądzi, że Probus miał zamiar stworzyć królestwo o charakterze uniwersalnym, polskim ${ }^{4}$. Wydaje się jednak, że te projekty Henryka $z$ lat osiemdziesiątych XIII $w$. należy umieścić raczej $w$ sferze marzeń, niż realnych możliwości. Henryk wprawdzie teoretycznie mógłby utworzyć jakieś ,królestwo wrocławskie”, po uzyskaniu zgody papieża i znalezieniu arcybiskupa, który chcialby go koronować, ale rozszerzenie granic takiego miniaturowego „królestwa” i nadanie mu odpowiedniego znaczenia było raczej niemożliwe bez konfliktu $\mathrm{z}$ którymś $\mathrm{z}$ sąsiadów, nie mówiąc już o tym, że możliwość realizacji obu tych niezbędnych warunków wydaje się raczej wątpliwa. I choć sytuacja finansowa Henryka była dość dobra, trudno przypuścić, by dzięki niej mógł on stworzyć w ówczesnych warunkach tak znaczną silę militarną, by podbić swoich sąsiadów, lub chociażby wymusić na nich uznanie swej zwierzchności. Przy optymalnym dla Henryka przebiegu wydarzeń mógłby on liczyć jedynie na zamianę tytułu książęcego na królewski, bez jakichkolwiek dalszych konsekwencji tego wydarzenia.

Jeśli więc Henryk rzeczywiście poważnie traktował obietnicę daną teściowi, to chyba po bardzo krótkim czasie doszedł do przekonania, że realizacja jej w ówczesnych warunkach byla zupełnie niemoźliwa. Nic też dziwnego, że z okresu najbliższych lat po jej uczynieniu nie mamy żadnych wiadomości o ewentualnych staraniach księcia o koronę królewską.

Sama zresztą wiadomość o tej deklaracji pochodzi z okresu nieco późniejszego, $\mathrm{z}$ lat $1287-1288$. W tym czasie bowiem Henryk porzucil już żonę i zawarł nowe małżeństwo z Matyldą (Mechtyldą) brandenburską ${ }^{5}$. I choć teść Henryka, Władysław opolski, już wówczas nie żył, to żyli jego synowie, bracia porzuconej żony Henryka, którzy stając w obronie siostry, przypomnieli mu ową obietnicę ${ }^{6}$. Sprawa ta jednak nie miała dalszego ciągu, gdyż pierwsza żona Henryka zmarła wkrótce po jego ślubie z Matyldą, a może nawet - jak przypuszczają niektórzy historycy - jeszcze przed tym faktem.

\footnotetext{
${ }^{3}$ R. Grodeck i, Plany koronacyjne ks. wroclawskiego Henryka IV, Śląsk 1946, R. I, nr 2, s. 4.

${ }^{4}$ Ibidem, s. 5-6; R. Grode ck i, Dzieje polityczne Ślaska do r. 1290, [w:] Historia Ślaska od najdawniejszych czasów do roku 1400, t. I, Kraków 1933, s. 291.

5 W. Dworzaczek, Genealogia..., tabl. 5; K. J a sińsk i, Rodowód..., t. I, s. 161.

${ }^{6}$ R. Grodecki, Dzieje polityczne Ślqska..., s. 293-294, 304-305.
} 
3. Rok 1288 przyniósł jednak też znaczne wzmocnienie pozycji Henryka i rozszerzenie obszaru, którym wladał, co bez kwestii mogło przybliżyć urealnienie jego królewskich aspiracji. Dotychczas bowiem Henryk aspiracji tych nie ujawniał; w każdym razie w źródlach nie przechowały się żadne ich ślady. Dnia 30 września 1288 r. zmarł bezpotomnie Leszek Czarny - książę krakowski, sandomierski, łęczycki i sieradzki ${ }^{7}$. Odziedziczone przez Leszka, po ojcu Kazimierzu kujawskim, księstwo sieradzkie opanowal bez trudu przyrodni brat zmarlego - Władyslaw Łokietek.

Natomiast księstwa krakowskie i sandomierskie Leszek chcial - jak się wydaje - przeznaczyć po swojej śmierci Henrykowi Probusowi, a kandydature tę popierało zarówno mieszczaństwo krakowskie, w dużej mierze pochodzenia niemieckiego, jak i dawni bliscy wspólpracownicy Leszka $\mathrm{z}$ kasztelanem krakowskim Sulkiem z Niedźwiedzia na czele, którzy opanowali Kraków wraz z Wawelem. Jednak osobie Henryka przeciwni byli dawni oponenci Leszka, którym przewodził biskup krakowski Paweł z Przemankowa, wahając się między kandydaturami Konrada II czerskiego, Bolesława II płockiego i Władysława Łokietka.

Pierwszy podjął inicjatywę Konrad. Wyprawił się on na Lublin, jednakże nie udało się mu zająć miasta, gdyż zastal bramy zamknięte. Tymczasem zebrana pod Sandomierzem szlachta, $\mathrm{z}$ inspiracji biskupa Pawła, wybrała swym księciem Bolesława płockiego, którego poparł Władysław Lokietek. Zanim jednak Łokietek zdołal wybrać się do Krakowa, gród opanował Henryk, mający wsparcie kasztelana Sulka i niemieckiego mieszczaństwa ${ }^{8}$.

Jednakże Henrykowi nie udało się utrzymać Krakowa na dłużej, mimo pomocy, której udzielili mu książęta śląscy: Henryk legnicki, Przemysł szprotawski i Bolesław opolski. Z końcem lutego 1289 r. Bolesław II płocki i Władyslaw Łokietek pobili oddziały śląskie pod Siewierzem; zginąl wówczas Przemysł szprotawski, a Bolesław opolski dostał się do niewoli. Po tej bitwie Łokietek opanowal Kraków, nie mógł jednak, mimo pomocy ze strony księcia halicko-włodzimierskiego Lwa I, zdobyć Wawelu. Z końcem lipca 1289 r. oddziały ruskie ruszyły na Śląsk łupiąc kraj aż po Nysę. Dopiero po wycofaniu się Rusinów, Henryk legnicki w porozumieniu z Henrykiem Probusem zajął Kraków, z którego w ostatniej chwili uciekł Lokietek.

Tym razem ziemia krakowska znalazła się definitywnie w rękach Henryka IV. Łokietek jednakże utrzymał się w Sandomierskiem ${ }^{9}$. Henryk Probus

\footnotetext{
${ }^{7}$ O. B a 1 zer, Genealogia Piastów, Kraków 1895, s. 332-333; W. D w or z a c zek, Genealogia..., tabl. 3.

${ }^{8}$ Rocznik Traski, [w:] Monumenta Poloniae Historica, l. II, Lwów 1872, s. 852; Rocznik Sedziwoja, ibidem, s. 878-879; S. Zachorowski, Wiek XIII $i$ panowanie Wladyslawa Lokietka, [w:] Dzieje Polski średniowiecznej, t. I (do roku 1333), Kraków 1926, s. 334-335.

${ }^{9}$ Ibidem, s. 339-340.
} 
- jak się wydaje - nie podjął na razie żadnych działań zbrojnych przeciwko Łokietkowi, choć jego rządy w księstwie sandomierskim uważał za uzurpację, o czym przekonuje używana wówczas przez Henryka tytulatura i jego testament.

Zapewne jednak opanowanie ziemi krakowskiej spowodowało, że Henryk dostrzegł w powstałej sytuacji możliwość realizacji swych dawnych marzeń o koronie królewskiej. Kraków był bowiem nie tylko stolicą królestwa Bolesława Śmiałego, a później - po śmierci Bolesława Krzywoustego - siedzibą princepsa, lecz w mieście tym była przechowywana korona królewska, a zapewne też i inne insygnia władzy, jak berło czy jabłko.

4. Nasuwa się jednak pytanie, o jakie królestwo mógł się ubiegać Henryk, a ściślej rzecz biorąc - na utworzenie jakiego królestwa mógł on uzyskać zgodę papieża?

Taka wątpliwość może wydawać się bezpodstawną, skoro w powszechnej opinii plany Henryka odnosić się mialy do restytucji królestwa polskiego. Tak sądził K. Maleczyński ${ }^{10}$, a i wcześniej R. Grodecki stwierdzal, że zamiarem zatem Henryka IV byla restytucja królewskiej godności o charakterze uniwersalnym, polskim ${ }^{11}$. S. Zachorowski pisze tylko, że Henryk staral sie o korone królewska ${ }^{12}$, ale już tytułem podrozdziału Testament Henryka IV $i$ jego plany odbudowania Polski $i^{13}$, wyraźnie daje do zrozumienia, że uważa, iż Henryk starał się o koronę polską.

Poglądy znakomitych uczonych, przyjmujące za oczywiste, że Henryk mógł podejmować starania tylko o koronę polską (bo o inną według nich przecież starać się nie mógł!), zostały przyjęte bez sprzeciwu przez ogół historyków i trafily do podręczników szkolnych. Tymczasem sprawa nie jest bynajmniej taka prosta.

Zwolennikom tego poglądu umknąl bowiem z pamięci bezsporny fakt, że w XIII w. nazwa „Polska" nie była jeszcze pojęciem geograficznie jednoznacznym. Slowo to wówczas oznaczało całość ziem pozostających pod rządami książąt $\mathrm{z}$ dynastii Piastów i tworzących prawie jednolity etnicznie i językowo obszar ${ }^{14}$. Jednakże mogło mieć też $i$ inne znaczenie. Pojęciem tym określano bowiem też terytorium znacznie mniejsze - samą Wielkopolskę - co w drugiej połowie XIII w. zaczęło utrwalać się w dokumen-

${ }^{10} \mathrm{~K}$. Maleczyński, Ślqsk $w$ epoce feudalnej, [w:] Historia Ślaska do roku 1763, red. K. M a leczyński, cz. I, do polowy XIV, Wrocław 1960, s. 527-528.

$"$ Por. wyżej.

${ }^{12}$ S. Za chorowski, Wiek XIII..., s. 337.

${ }_{13}$ Ibidem, s. 341-342.

14 Tak najpewniej to słowo rozumiała hierarchia kościelna, a przede wszystkim Jakub Świnka, którego władzy metropolitalnej cały ten obszar podlegał. 
tach, a najprawdopodobniej też $w$ stosunkach międzypaństwowych. W tym czasie bowiem już tylko wladcy Wielkopolski tytułowali się ,,książętami Polski", a u innych książąt dzielnicowych tytuł ,polski" zniknął zupełnie. W traktatach i umowach zawieranych pomiędzy nimi "Polska" (rozumiana jako Wielkopolska) traktowana jest na równi z innymi dzielnicami - krakowską, sieradzką czy Pomorzem, a książę „Polski” nie jest nawet pod względem formalnym inaczej traktowany, niż władcy pozostałych dzielnic ${ }^{15}$.

W tej sytuacji utworzenie „królestwa polskiego”, które obejmowałoby tylko ziemię krakowską, a może i dzielnicę wrocławską, jednak z pominięciem Wielkopolski określanej często przecież mianem Polski, byłoby niemożliwe bez wywolania konfliktu na dużą skalę, a może nawet interwencji zbrojnej. Można by się wówczas spodziewać nie tylko gwałtownych protestów ze strony Przemysla II, ale i pozostałych książąt dzielnicowych, mogących słusznie obawiać się, że Henryk będzie dążyć do rozciągnięcia swej władzy nie tylko na Wielkopolskę, ale i na ich posiadłości. Przy całym, niewątpliwie dużym zasobie zarówno gospodarczym, jak i militarnym księcia wrocławskiego, trudno sądzić, by nie zdawal on sobie sprawy, że prawdopodobnie nie mógłby wytrzymać przewagi sił zbrojnych zjednoczonych przeciwko niemu Piastów; musiał też niewątpliwie pamiętać o poniesionej tak niedawno klęsce pod Siewierzem.

Do tego mogły dojść komplikacje natury politycznej i dyplomatycznej, a przede wszystkim zatargi $\mathrm{z}$ hierarchią kościelną. Trudno bowiem sobie wyobrazić, by obok "księstwa polskiego" powstało sąsiadujące z nim „,królestwo polskie”, nie obejmujące ani piędzi ziemi w Wielkopolsce, identyfikowanej wówczas dość powszechnie z Polską właściwą, a w każdym razie uważanej za zasadniczą i integralną jej część. Czy władca takiego „królestwa polskiego" mógłby liczyć na uzyskanie zgody papieskiej na powstanie dziwacznego tworu i otrzymanie korony polskiej z rąk tak ściśle związanego z Przemysłem II, metropolity całej Polski, Jakuba Świnki? Wydaje się to więcej niż wątpliwe. Zresztą istnienie obok siebie dwu państw o identycznej nazwie i różniących się jedynie książęcym i królewskim tytułem ich władców stwarzałoby bezprecedensową w XIII w. i zgola dziwną, jeśli nawet nie konfliktową sytuację ${ }^{16}$. Trudno też sobie wyobrazić, by Henryk - realista mógł choć próbować wcielać w życie tak fantastyczne plany.

is Por. Dokumenty kujawskie i mazowieckie, przeważnie z XIII wieku, zebr. i wyd. B. Ulanowski, AKH [Kraków] 1888, t. 4, Dokumenty kujawskie, nr 46; KDWp, t. I, wyd. I. Zakrzewski, Poznań 1877, nr 584; ZDM, cz. IV, wyd. S. Kuraś, Wrocław 1969, nr 886.

${ }^{16}$ Podobna sytuacja istniała wprawdzie niegdy's w Burgundii, gdzie obok królestwa istniało księstwo, a nawet i hrabstwo o tej samej nazwie, ale było to na przelomie X i XI w. W XIII w. taki uklad bylby zupehnym anachronizmem. 
Trzeba zresztą $\mathrm{z}$ naciskiem podkreślić, że informacje $\mathrm{o}$ tym, jakoby Henryk podejmowal realne działania w sprawie restytucji królestwa polskiego, wynikają wyłącznie z mylnej interpretacji źródła. Oczywiście, nie znaczy to, że chcemy wykluczyć, iż Henryk myślał o tym, by w przyszłości zjednoczyć całą Polskę pod swym berłem. O tym jednak żadne źródła nic nie mówią.

Jedynym źródłem, które informuje o zabiegach Henryka o koronę królewską, jest kronika Ottona styryjskiego. Według jego relacji, Henryk wysłał na zachód czlowieka zaufanego, zaopatrzonego w znaczną sumę pieniędzy, celem poparcia starań o uzyskanie korony królewskiej. Tymczasem ów człowiek po prostu pieniądze te ukradł, a dla zatarcia śladów, brat złodzieja, który był lekarzem księcia, otruł Henryka ${ }^{17}$.

Trzeba podkreślić jednak, że źródło to, z którego zaczerpnęli informacje zarówno R. Grodecki, jak i K. Maleczyński, bynajmniej nie mówi o tym, by Henryk staral się o koronę polską. Przeciwnie; stwierdza ono wyraźnie, że Henryk chciał utworzenia królestwa w Krakowie (ein kunigrich zu Krakou $)^{18}$. Wynika więc $\mathrm{z}$ tego, że Henryk pragnąl utworzenia nowego „królestwa krakowskiego”, co mogłoby też wzbudzić niechęć innych Piastów, ale nie mogło stać się formalną podstawą do jakiejś akcji przeciwko Probusowi, nawet ze strony Przemysła II.

Można też sądzić, że takie nowe królestwo miałoby szanse na uzyskanie aprobaty papieskiej, o ile tylko jego utworzenie nie naruszałoby w niczym praw metropolitalnych arcybiskupa gnieźnieńskiego. Nie każde przecież powstałe w średniowieczu królestwo mogło od początku istnienia poszczycić się własną metropolią, jak to widzimy na przykładzie Czech.

O planach koronacyjnych Henryka informuje tylko jedno źródło - kronika Ottona styryjskiego. K. Maleczyński, akceptując informację, odrzuca jednak tę jej część, która mówi o kradzieży pieniędzy. Przypuszcza on, że nie jakieś malwersacje finansowe pelnomocnika Henrykowego $w$ Rzymie, ale nieznane bliżej machinacje obozu wrogiego planom koronacyjnym Probusa spowodowaly nieudanie sie misji jego wysłańców ${ }^{19}$. Niestety, autor ten nie wyjaśnił, na jakich przesłankach oparł swoje przypuszczenie.

Zakładając, że Henryk staral się o koronę polską, S. Zachorowski, a za nim K. Maleczyński, omawiając treść testamentu Probusa, widzą w nim zaplanowane, powolne dążenie do jednoczenia ziem Polski. Zadanie to po Przemyśle II miał przejąć Henryk glogowski, gdyż - jak podkreśla S. Zachorowski - Przemysł nie mial syna ${ }^{20}$. Należy jednak $z$ naciskiem

${ }^{17}$ Ottokars Reimehronik, hrsgb. von J. Seemüller, [w:] Monumenta Germaniae Historica, Deutsche Chroniken, t. V/1, Hannower 1890, s. 286.

${ }^{18}$ Ibidem, s. 286; por. też Scriptores rerum Austriacarum, t. IV, hrsgb. von H. Pez, Ratisbonae 1745 , s. $196-199$.

${ }^{19}$ K. M a leczyński, Ślask..., s. 524.

${ }^{20}$ S. Zachorowski, Wiek XIII..., s. 341; K. Maleczyński, Slqusk..., s. 527-528. 
przypomnieć, że są to jedynie spekulacje. Probus nie mógł przecież przewidzieć, że Przemysł w przyszłości nie będzie mial syna, zwłaszcza że książę ten miał już wówczas półtoraroczną córkę. W przypadku zaś, gdyby Przemysł pozostawil potomka męskiego, to Henryk głogowski nie mógłby oczywiście objąć ani Wielkopolski, ani ziemi krakowskiej. W dodatku przecież nie sposób było wówczas przewidzieć, czy wcześniej umrze Przemysł, czy władca Głogowa, zwłaszcza że obaj byli mniej więcej w tym samym wieku.

Jeśli zaś założyć, że Henryk Probus nie starał się bynajmniej o restytucję królestwa polskiego, ale pragnął utworzyć dla siebie nowe królestwo krakowskie, na co zdaje się wskazywać tekst cytowanej kroniki, to tym bardziej przypuszczenia obu tych autorów nie mają żadnej konkretnej podstawy.

5. Charakterystyczne, że inni autorzy, choć piszą o królewskich aspiracjach Henryka, unikają wyraźnego stwierdzenia, że w planach księcia leżala właśnie restytucja królestwa polskiego. Stefan Sobaniec -- autor jednego $z$ nielicznych artykulów poświęconych tym aspiracjom - choć w tytule swej pracy pisze o usiłowaniach Henryka odnowienia królestwa, to jednak w jej tekście stwierdza tylko, że Henryk starał się odnowić korone królewska ${ }^{21}$, a w innym miejscu, że Henryk staral się o królestwo w Krakowie ${ }^{22}$. Józef Mitkowski - autor życiorysu Henryka w Polskim Slowniku Biograficznym - wspomina wprawdzie o staraniach Henryka o koronę, ale nie precyzuje, o jaką koronę książę się ubiegat ${ }^{23}$. Autor zaś najnowszej syntezy średniowiecznych dziejów Polski - Jerzy Wyrozumski - stwierdza też tylko, że podjal Henryk starania o korone królewskq, w trakcie których zginal otruty $(1290)^{24}$, nie wskazując jednak wyraźnie, czy Henryk starał się o koronę polską, czy też o krakowską. Tak więc biorąc pod uwagę zarówno tekst źródła, jak i rozważając ówczesną sytuację z prawnego i dyplomatycznego punktu widzenia, należy przyjąć, że Henryk mógł starać się najwyżej o utworzenie nowego królestwa - krakowskiego, gdyż tylko takie starania mialy jakieś szanse powodzenia. Natomiast możliwość restytucji królestwa polskiego pod berłem Henryka w sytuacji, gdy nie wladał on Wielkopolska (nazywaną wówczas bardzo często po prostu „Polską”), mającą w dodatku władcę w osobie Przemysła II, popieranego zgodnie przez całą hierarchię polską z Jakubem Świnką na czele, wydaje się bardzo mało prawdopodobna.

\footnotetext{
${ }^{21}$ S. S o ban iec, Zabiegi Henryka IV wroclawskiego o Kraków $i$ jego usilowania odnowienia Królestwa, [w:] Ksiega ku czci Oskara Haleckiego wydana w XXV-lecie jego pracy naukowej, Warszawa 1935, s. 242.

22 Ibidem, s. 246.

${ }^{23}$ J. Mitk owski, Henryk IV Probus (Prawy), (ok. 1257-1290), ksiażze ślaski i krakowski, [w:] Polski slownik biograficzny, t. IX, Wroclaw 1960-1961, s. 407.

${ }^{24}$ J. Wyrozumski, Historia Polski do roku 1505, wyd. 13, Warszawa 1989, s. 139.
} 
Nawet bowiem gdyby założyć, że papież do tego stopnia nie orientowal się $w$ stosunkach polskich, iż udzieliłby Henrykowi zezwolenia na koronację na króla Polski, to nie sądzę, by Świnka w dobrze pojętym interesie Kościoła (i własnym!) nie zapobiegłby realizacji tego zezwolenia. Jest zresztą też mało prawdopodobne, by Stolica Apostolska zdecydowala się na tak poważne posunięcia bez konsultacji z arcybiskupem gnieźnieńskim.

Oczywiście, powyższe wywody nie świadczą o tym, by Henryk odrzucał myśl pozyskania korony polskiej w bliżej nie sprecyzowanej przyszłości i przy powstaniu sprzyjających temu okoliczności. Jednakże stwierdzić trzeba, że okoliczności takich w 1290 r. nie było i nic wówczas nie wskazywało na to, by mogły one w najbliższym czasie powstać. 